\title{
PENERAPAN MODEL PEMBELAJARAN KOOPERATIF TIPE MEANS ENDS ANALYSIS SEBAGAI UPAYA MENINGKATKAN KEAKTIFAN DAN HASIL BELAJAR MATEMATIKA SISWA MATERI LIMIT FUNGSI
}

\author{
Ermi $^{1}$, Siti Khodijah ${ }^{2}$, Wiwit Damayanti Lestari ${ }^{3}$ \\ ${ }^{1}$ Guru Matematika, ${ }^{2}$ Mahasiswa Prodi Pendidikan Matematika, ${ }^{3}$ Dosen Prodi Pendidikan \\ Matematika ${ }^{1}$ MA Negeri 1 Indramayu, ${ }^{2,3}$ FKIP - Universitas Wiralodra \\ 1'hjermi54@gmail.com, ${ }^{2}$ khodijahsiti1396@gmail.com, \\ ${ }^{3}$ wiwitdamayantilestari@unwir.ac.id
}

\begin{abstract}
Abstrak
Penelitian ini bertujuan untuk mengetahui apakah penerapan model pembelajaran kooperatif tipe Means End Analysis dapat meningkatkan keaktifan dan hasil belajar materi limit fungsi. Penelitian ini merupakan Penelitian Tindakan Kelas yang dilakukan di MA Negeri 1 Indramayu. Subjek dalam penelitian ini adalah siswa kelas XI-2 MIA yang berjumlah 23 siswa. Instrumen yang digunakan dalam penelitian ini adalah lembar observasi siswa yang bertujuan untuk mengukur keaktifan belajar dan tes formatif yang diberikan pada tiap siklus yang bertujuan untuk mengukur peningkatan hasil belajar materi limit fungsi. Hasil pengolahan data hasil belajar matematika siswa diperoreh bahwa terjadi peningkatan rata-rata tiap siklus. Hasil pengolahan data keaktifan diperoreh bahwa terjadi peningkatan rata-rata tiap siklus. Sehingga penerapan model pembelajaran kooperatif tipe Means End Analysis efektif dan dapat meningkatkan keaktifan dan hasil belajar materi limit fungsi.
\end{abstract}

Kata kunci: model pembelajaran kooperatif tipe Means Ends Analysis (MEA), keaktifan, dan hasil belajar materi limit fungsi

\section{A. Pendahuluan}

Pendidikan pada dasarnya merupakan proses untuk membantu manusia dalam mengembangkan dirinya sehingga mampu menghadapi setiap perubahan yang terjadi. Perubahan dan perkembangan ilmu pengetahuan dan teknologi yang semakin pesat maka perlu diikuti oleh kinerja pendidikan yang profesional dan bermutu tinggi. Lembaga pendidikan bermutu menjadi salah satu pengharapan yang besar di negeri ini agar bisa bangkit dari kualitas pendidikan yang belum memuaskan dalam semua aspek dan jenjang pendidikan. Kualitas pendidikan yang baik sangat diperlukan untuk mendukung terciptanya insan yang cerdas, terampil, kreatif, inovatif, dan adaptif agar bisa bersaing secara terbuka di era global. Oleh karena itu diperlukan adanya pembenahan dan penyempurnaan 
terhadap aspek substantif dalam penyelenggaraan pendidikan, terutama kurikulum dan tenaga profesional yang melaksanakan kurikulum tersebut yaitu tenaga pendidik. Kualitas pendidikan di suatu negara dapat dilihat dari proses pembelajaran di sekolah, dimana pembelajaran yang bertujuan untuk mempersiapkan peserta didik menghadapi perubahan dunia dengan menekankan pada penalaran logis, rasional, dan kritis, serta memberikan keterampilan kepada mereka untuk mampu mengaplikasikan pembelajaran yang didapatkan di sekolah khususnya pembelajaran matematika dalam kehidupan sehari-hari.

Matematika merupakan ilmu universal yang mendasari segala ilmu sehingga matematika merupakan mata pelajaran yang wajib dipelajari di sekolah dan perguruan tinggi. Matematika mempunyai peranan penting dalam berbagai ilmu, dan memajukan daya berfikir manusia. Berdasarkan hasil studi Programme for International Student Assessment (PISA) tahun 2018 yang menunjukkan bahwa bidang Matematika skor rata-rata siswa Indonesia mencapai 379 dibawah skor rata-rata OECD 487 (Kemdikbud, 2019). Salah satu yang mempengaruhi rendahnya prestasi belajar siswa dikarenakan kurangnya pemahaman siswa terhadap materi pembelajaran. Salah satu penyebab ketidakpahaman siswa tentang matematika adalah cara mengajar guru di kelas, seringnya guru menggunakan model pembelajaran konvensional dalam proses belajar mengajar menyebabkan siswa tidak berperan aktif dalam pembelajaran. Model yang sering digunakan dalam pembelajaran lebih berpusat pada guru (Teacher Center) dan siswa lebih berperan sebagi penerima informasi, mencatat dan mendengarkan apa yang disampaikan oleh guru, yang akhirnya berimplikasi pada rendahnya hasil belajar siswa.

Haris Kerdia (Utari Soemarmo, 2017: 8) menyatakan pendidikan matematika di tanah air saat ini sedang mengalami perubahan paradigma. Terdapat kesadaran yang kuat, terutama dikalangan pengambil kebijakan, untuk memperbaharui pendidikan matematika. Salah satu kecakapan dan kemahiran matematika yang diharapkan dapat tercapai dalam belajar matematika mulai dari SD/MI hingga SMA/MA adalah menunjukan pemahaman konsep matematika yang dipelajari, menjelaskan keterkaitan konsep dan mengaplikasikan konsep secara luwes, akurat, efesien, dan tepat, dalam pemecahan masalah. 
Dalam kecakapan ini, tampak bahwa setelah siswa mendapatkan pembelajaran, siswa diharapakan mampu menerapkan ide-ide matematika siswa untuk memperoleh pengalaman menggunakan pengetahuan serta keterampilan yang sudah dimilikinya dengan cara membuat keterkaitan antar konsep, baik antar konsep dalam matematika itu sendiri maupun relevansi konsep matematika dengan bidang lain dan dengan permasalahan kehidupan sehari-hari. Untuk itu diperlukan model pembelajaran secara kelompok yang memfasilitasi siswa mampu mengungkapkan beberapa pendapat bersama temannya untuk mengkonstruksi pengetahuan dari aktifitas belajar. Secara garis besar, paham kontruktivisme menghendaki bahwa dalam proses pembelajaran, peran aktif siswa harus lebih ditekankan sehiungga dalam belajar, siswa tidak hanya menerima saja, tetapi siswa juga menjadi kreator yang mengkonstruksi pemahamannya sendiri. Dengan demikian, diharapkan siswa akan mencapai suatu kebermaknaan dalam belajar.

Berdasarkan permasalahan diatas, maka perlu diterapkan suatu model pembelajaran yang dapat melibatkan siswa secara aktif dalam pembelajaran matematika, sehingga dapat mengaktifkan interaksi antara siswa dengan guru, dan siswa dengan siswa, serta siswa dengan bahan pelajarannya. Dengan demikian, pembelajaran matematika diarahkan pada aktivitas siswa yang terampil dalam menemukan dan memahami konsep-konsep atau prinsip-prinsip dalam matematika. Jika siswa telah memahami konsep matematika tersebut, maka meraka mampu memecahkan atau menyelesaikan soa-soal yang berkaitan dengan konsep matematika yang diajarkan. Salah satu solusi untuk memecahkan masalah tersebut dengan menerapkan suatu model pembelajaran kooperatif tipe Means Ends Analysis (MEA).

Berdasarkan hasil observasi yang dilakukan selama pembelajaran sebelumnya, siswa kelas XI-MIA MA Negeri 1 Indramayu mengalami kesulitan dalam mempelajari materi limit fungsi. Kemampuan pemahaman siswa dalam menyelesaikan masalah limit fungsi masih rendah. Hal tersebut akan berakibat pada hasil belajar matematika dan persentase ketuntasan KKM siswa yang masih rendah, dimana KKM MA Negeri Indramayu adalah 75. Agar kesulitan yang dihadapi siswa dapat diatasi dan hasil belajar matematika siswa pada soal-soal 
limit fungsi dapat ditingkatkan, tentu dibutuhkan suatu model pembelajaran yang tepat. Guru perlu menerapkan suatu model pembelajaran yang melibatkan siswa secara aktif dalam proses pembelajarannya. Sehingga diharapkan siswa dapat menyelesaikan soal-soal dalam bentuk aplikasi dan dapat meningkatkan hasil belajar matematikanya. Model pembelajaran matematika yang dipilih pada penelitian ini adalah model pembelajaran MEA.

Hasil Belajar merupakan hasil dari suatu interaksi tindak belajar dan tindak mengajar (Mudjiono, 2006). Berdasarkan hal tersebut hasil belajar merupakan hasil yang didapat setelah terjadinya proses belajar mengajar. Hal tersebut sesuai dengan pendapat Sudjana (2013) bahwa hasil belajar merupakan kemampuankemampuan yang dimiliki siswa setelah ia menerima pengalaman belajarnya. Hasil peristiwa belajar dapat muncul dalam berbagai jenis perubahan atau pembuktian tingkah laku seseorang. Dari pengertian tersebut dapat ditarik kesimpulan bahwa hasil belajar materi limit fungsi pada penelitian ini adalah hasil yang diperoleh siswa setelah menerima proses belajar dan hasil tersebut dapat berupa kemampuan-kemampuan yang berkaitan dengan apa yang telah siswa pelajari serta perubahan atau pembuktian tingkah laku.

Keaktifan siswa selama proses belajar mengajar menjadi salah satu indikator adanya keinginan atau motivasi siswa tersebut dalam belajar. Belajar aktif pada pelaksanaannya melibatkan semua aspek, baik fisik, mental maupun emosional siswa yang tercermin pada kemampuan kognitif, afektif, dan psikomotor siswa. Siswa dikatakan memiliki keaktifan apabila ditemukan ciri-ciri perilaku seperti: sering bertanya kepada guru atau siswa lain, mengerjakan tugas yang diberikan guru, mampu menjawab pertanyaan, senang diberi tugas belajar, memiliki pemahaman yang baik terhadap materi pembelajaran, dan lain sebagainya. Keaktifan siswa dalam proses pembelajaran akan menyebabkan interaksi yang tinggi antara guru dengan siswa ataupun dengan siswa itu sendiri. Hal ini akan mengakibatkan suasana kelas menjadi dinamis dan kondusif, dimana masing-masing siswa dapat memaksimalkan kemampuannya.

Menurut Warsono \& Hariyanto (Wahyono, 2017), penelitian tentang pembelajaran kooperatif sudah dimulai sejak tahun 1970-an membuktikan bahwa penerapan teknik pembelajaran kooperatif antara lain dapat memberikan manfaat 
berupa: meningkatkan kualitas hasil pembelajaran dan prestasi akademik, meningkatkan kemampuan mengingat para siswa, meningkatkan kepuasan siswa terhadap pengalaman belajarnya, membantu siswa mengembangkan keterampilan komunikasi dan sosial siswa, memberi motivasi kepada siswa untuk mempelajari bahan pembelajaran dengan lebih baik, meningkatkan rasa percaya diri siswa, membantu meningkatkan hubungan positif antar suku/ ras. Menurut Isjoni (2011), model pembelajaran kooperatif adalah suatu model pembelajaran yang digunakan untuk mewujudkan kegiatan belajar mengajar yang perpusat pada siswa (student oriented), untuk mengatasi permasalahan yang ditemukan guru terhadap siswa yang tidak bekerja sama dengan orang lain.

Dari beberapa pengertian di atas dapat disimpulkan bahwa, model pembelajaran kooperatif adalah suatu pola pembelajaran yang dapat digunakan untuk merencanakan dan membimbing bahan belajar dikelas, agar kegiatan belajar mengajar berpusat pada siswa, serta untuk mengatasi permasalahan yang ditemukan guru untuk mengaktifkan siswa dalam proses belajar. Pembelajaran MEA merupakan salah satu desain pembelajaran yang berorientasi pada masalah dan tujuan secara keseluruhan. Tujuan tersebut dijadikan ke dalam beberapa tujuan untuk menetapkan langkah-langkah kegiatan belajar yang mengacu pada materi ajar. Menurut Fitriani (2012: 68), MEA adalah suatu proses yang digunakan pada pemecahan masalah yang mencoba untuk mereduksi perbedaan antara current state (pernyataan sekarang) dan goal state (tujuan). Current State merupakan suatu informasi baru hasil dari pemecahan masalah berdasarkan tujuan. Sedangkan goal stste, merupakan suatu hasil yang akan dicapai siswa dari permasalahan tersebut. Sehingga, tujuan dalam penelitian ini adalah untuk mengetahui apakah penerapan model pembelajaran kooperatif tipe MEA dapat meningkatkan keaktifan dan hasil belajar materi limit fungsi pada siswa kelas XI2 MIA MA Negeri 1 Indramayu.

\section{B. Metode Penelitian}

Penelitian ini merupakan Penelitian Tindakan Kelas (PTK) yang dilakukan di MA Negeri 1 Indramayu tahun pelajaran 2018/2019. Subjek dalam penelitian ini adalah siswa kelas XI-2 MIA yang berjumlah 23 siswa. Variabel yang diamati dalam penelitian ini adalah keaktifan dan hasil belajar siswa pada materi limit 
fungsi. Teknik penelitian yang digunakan yaitu observasi dan tes tertulis. Penelitian terdiri dari 3 siklus, dan setiap siklus terdiri dari 4 tahap yaitu perencanaan (planning), pelaksanaan (action), observasi (observation), refleksi (reflection).

\section{Hasil Dan Pembahasan}

Berdasarkan hasil pengolahan data hasil tes yang dilakukan tiap akhir siklus, diperoleh analisis data sebagai berikut.

Tabel 1. Ketuntasan Siswa dalam Pembelajaran

\begin{tabular}{lccc}
\hline \multicolumn{1}{c}{ Keterangan } & \multicolumn{3}{c}{ Nilai Tes Siswa Pada Tiap Siklus } \\
& I & II & III \\
\hline $\begin{array}{l}\text { Rata-rata Skor Hasil } \\
\text { Belajar Matematika }\end{array}$ & 73,87 & 79,30 & 85,65 \\
$\begin{array}{l}\text { Presentase Siswa yang } \\
\text { Tuntas }\end{array}$ & $62,50 \%$ & $83,33 \%$ & $87,50 \%$ \\
\hline
\end{tabular}

Ketuntasan belajar yang disajikan dalam tabel 1 memperlihatkan bahwa ratarata skor tes siswa pada siklus I sebesar 73,87. Dari tabel tersebut terlihat bahwa siswa yang tuntas belajarnya pada tindakan pertama sebanyak 15 dari 23 siswa yang mengikuti tes pada siklus I. Jadi presentase siswa yang tuntas belajarnya adalah $62,50 \%$. Dalam hal ini kriteria menurut Kurikulum dapat disimpulkan bahwa tindakan pada siklus 1 tinggi. Pada siklus II, rata-rata skor tes siswa sebesar 79,30\% dan jumlah siswa yang tuntas pada pembelajaran di siklus II sebanyak 20 dari 23 yang mengikuti tes pada siklus II. Sehingga presentase ketuntasan belajarnya adalah 83,33\%. Dalam hal ini kriteria menurut kurikulum dapat disimpulkan bahwa tindakan pada siklus II tergolong sangat tinggi. Pada siklus III, rata-rata skor tes siswa sebesar 85,65 dan jumlah siswa yang tuntas pada pembelajaran di siklus III sebanyak 21 dari 23 yang mengikuti tes pada siklus III. Sehingga presentase ketuntasan belajarnya adalah $87,50 \%$ Dalam hal ini kriteria menurut Kurikulum dapat disimpulkan bahwa tindakan pada siklus III tergolong sangat tinggi. 
Selain pengolahan data, pelaksanaan pembelajaran juga perlu adanya penilaian dan observasi. Pelaksanaan pembelajaran ini di amati oleh 2 observer. Pada tahap pelaksanaan terlihat dari hasil observasi yang dinilai oleh observer, aktifitas guru pada siklus I belum mencapai hasil yang baik, hal tersebut dikarenakan tahap perkenalan atau adaptasi antara guru dan siswa dengan model dan media pembelajaran. Adapun permasalahan pada siklus I yang ditemukan oleh observer 1 yaitu: tulisan dipapan tulis terlalu kecil; tidak disampaikan motivasi siswa dalam pembelajaran; tidak menyampaikan tujuan pembelajaran; kurang memanajemen waktu menyebabkan keterbatasan dalam waktu mengerjakan latihan soal; soal latihan jangan terlalu banyak. Sedangkan permasalahan yang ditemukan oleh observer 2 yaitu: ukuran tulisan guru pada papan tulis terlalu kecil sehingga kurang jelas terlihat dari belakang; waktu pembelajaran tidak sesuai dengan RPP; tujuan pembelajaran, motivasi dan langkah-langkah pembelajaran MEA belum disampaikan pada siswa dengan maksimal.

Dari hasil observasi terhadap siswa pada siklus I yang telah diberikan tindakan-tindakan pada instrumen keaktifan pada umumnya telah mencapai kategori aktif (A) yaitu rata-rata 2,69 2,75 dari 23 siswa yang mengikuti pembelajaran pada siklus I, yang dinyatakan tidak aktif sebanyak 10 siswa dan yang aktif sebanyak 13 siswa atau 56,52\%, karena target keaktifan $75 \%$ jadi pada siklus I belum mencapai kategori aktif.

Dari hasil refleksi yang dilakukan peneliti dan observer, maka upaya yang harus diperbaiki pada tindakan siklus ke II menurut observer 1 yaitu: ukuran tulisan diperbesar; diawal pembelajaran harus disampaikan motivasi dalam pembelajarannya; sampaikanlah tujuan pembelajaran agar siswa tahu tujuan pembelajaran yang akan dipelajari; kegiatan pembelajaran, seperti pendahuluan, inti dan penutup alokasi waktunya harus diperhitungkan; buat soal latihan maksimal 3. Sedangkan menurut observer 2 yaitu: perbesar ukuran tulisan dan gunakan spidol yang tintanya terisi penuh serta bersihkan sisa spidol pada papan tulis; letakan proyektor jauh dari papan tulis agar layar terlihat lebih besar dan perbesar ukuran font huruf dan angka; sesuaikan waktu pembelajaran dengan RPP; efesienkan penggunaan waktu agar tidak kelebihan dalam menggunakan 
waktu pembelajaran; sampaikan tujuan, motivasi, dan langkah pembelajaran MEA dalam pembelajaran dengan jelas pada siswa.

Pada tahap pelaksanaan siklus II terlihat dari hasil observasi yang dinilai oleh observer, aktifitas guru pada siklus II terdapat peningkatan, tapi belum mencapai hasil yang sempurna, hal tersebut terjadi dikarenakan guru lebih memperhatikan dan memperbaiki masalah-masalah dalam hasil refleksi yang terjadi pada siklus I. Adapun permasalahan yang ditemukan oleh observer 1 yaitu: kondisikan kelas sebelum belajar; pembagian kelompok kurang bervariasi, sehingga ada kelompok yang masih kurang aktif dalam proses pembelajaran; suara guru kurang lantang. Sedangkan permasalahan yang ditemukan observer 2 yaitu: kodisi kelas kurang kondusif, sehingga masih ada siswa yang masih belum sipa untuk belajar; suara guru kurang lantang, sehingga kurang terdengar dari belakang; posisi duduk lebih diatur lagi, supaya ada jalan untuk guru ketika mengawasi; masih ada siswa yang kerjasama ketika mengerjakan tes pada akhir siklus.

Dari hasil observasi terhadap siswa pada siklus II yang telah diberikan tindakan-tindakan pada instrumen keaktifan pada umumnya telah mencapai kategori aktif (A) yaitu rata-rata 3,20>2,75 dari 24 siswa yang mengikuti pembelajaran pada siklus II, yang dinyatakan tidak aktif sebanyak 5 siswa dan yang aktif sebanyak 18 siswa atau 78,26\%, karena target keaktifan $75 \%$ jadi pada siklus II mencapai kategori aktif. Aktivitas pada tindakan siklus II lebih baik dibandingkan dengan siklus I. Walaupun ada hal-hal yang harus diperhatikan demi pembelajaran selanjutnya. Hal ini sejalan dengan pendapat Warsono \& Hariyanto (Wahyono, 2017), yang menyatakan bahwa penerapan teknik pembelajaran kooperatif dapat memberikan manfaat berupa peningkatan kualitas hasil belajar dan memberi motivasi siswa dalam belajar yng tercermin dari aktivitas pembelajaran yang meningkat.

Dari hasil refleksi yang dilakukan peneliti dan observer, maka upaya yang harus diperbaiki pada tindakan siklus ke III menurut observer 1 yaitu: sebaiknya guru mempersiapkan kelas sebelum proses pembelajaran dimulai, agar kelas kondusif; usahakan pembagian kelompok bervariasi, agar siswa dengan kelompoknya saling berdiskusi dan aktif dalam pembelajaran; suara guru 
sebaiknya di lantangkan supaya terdengar dengan jelas sampai belakang. Sedangkan menurut observer 2 yaitu: baiknya kelas dikondisikan terlebih dahulu sebelum pembelajaaran dimulai; baiknya suara guru dipertegas dan dilantangkan, supaya siswa yang duduk dibagian belakang terdengar; atur posisi duduk kelompok dengan rapih dan usahakan ada jalan untuk guru, agar guru bisa mengawasi jalannya proses pembelajaaran; perketat pengawasan pada saat siswa sedang mengerjakan tes pada akhir siklus.

Pada tahap pelaksanaan terlihat dari hasil observasi yang dinilai oleh observer, aktifitas guru pada siklus III terdapat peningkatan dari yang sebelumnya, meski belum mencapai hasil yang sempurna, hal tersebut terjadi dikarenakan guru lebih memperhatikan dan memperbaiki masalah-masalah dalam hasil refleksi yang terjadi pada siklus II maupun masalah-masalah yang belum terselesaikan pada siklus II. Adapun permasalahan yang ditemukan oleh observer 1 pada siklus III yaitu: perlu memotivasi lebih anggota kelompok yang kurang aktif. Sedangkan menurut observer 2 yaitu: dalam menanggapi hasil presentasi lembar kerja siswa masih perlu diperkaya pembahasannya.

Dari hasil observasi terhadap siswa pada siklus III yang telah diberikan tindakan-tindakan pada instrumen keaktifan pada umumnya telah mencapai kategori aktif (A) yaitu rata-rata 3,83> 2,75 dari 23 siswa yang mengikuti pembelajaran pada siklus III, yang dinyatakan tidak aktif sebanyak 2 siswa dan yang aktif sebanyak 21 siswa atau 91,30\%, karena target keaktifan 75\% jadi pada siklus III mencapai kategori aktif.

Berdasarkan hasil penelitian dan analisis data ditemukan hasil sebagai berikut. 1) Penggunaan model pembelajaran MEA pada siklus I dan diawali pembelajaran dengan indikator Menunjukan limit kiri dan limit kanan pada suatu fungsi, belum dapat meningkatkan hasil belajar matematika siswa yaitu dari 23 siswa, sebanyak 15 siswa yang mencapai ketuntasan belajar dengan rata-rata kelas 73,87 atau dibawah KKM yaitu 75, dengan keaktifan siswa yaitu sebesar 56,52\% dari target $75 \%$. 2) Penggunaan model pembelajaran MEA pada siklus II dan diawali pembelajaran dengan indikator Menemukan limit suatu fungsi aljabar, serta dengan dilakukan refleksi dan tindakan-tindakan telah menunjukan perbaikan dan dapat meningkatkan hasil belajar matematika siswa yaitu dari 23 , 
sebanyak 20 siswa sudah mencapai ketuntasan belajar dengan rata-rata kelas 79,30 atau diatas KKM, begitu juga keaktifan siswa dalam belajar terjadi peningkatan yaitu $78,26 \%$ atau diatas $75 \%$. 3) Penggunaan model pembelajaran MEA pada siklus II dan diawali pembelajaran dengan indikator Menemukan limit suatu fungsi aljabar serta dengan dilakukan refleksi dan tindakan-tindakan telah menunjukan perbaikan dari pada siklus II hasil ini dapat dilihat dari meningkatnya hasil belajar matematika siswa yaitu dari 23 siswa, sebanyak 21 siswa sudah mencapai ketuntasan belajar dengan ratarata kelas 85,65 atau diatas KKM, begitu juga keaktifan siswa dalam belajar terjadi peningkatan yaitu 91,30\% atau diatas $75 \%$.

Penggunaan model pembelajaran MEA siklus I belum terlihat efektif meningkatkan keaktifan dan hasil belajar matematika siswa, tetapi penggunaan model pembelajaran MEA dari siklus II sampai dengan siklus III menunjukkan efektifitasnya dan benar bahwa penggunaan MEA dapat meningkatkan keaktifan dan hasil belajar matematika siswa pada materi limit fungsi.

\section{Kesimpulan}

Berdasarkan hasil dan pembahasan di atas, dapat disimpulkan bahwa penerapan model pembelajaran kooperatif tipe MEA dapat meningkatkan keaktifan dan hasil belajar materi limit fungsi pada siswa kelas XI-2 MIA MA Negeri 1 Indramayu.

\section{UCAPAN TERIMAKASIH}

Penulis menyampaikan terimakasih kepada MA Negeri 1 Indramayu yang telah menjadi tempat penelitian.

\section{Daftar Pustaka}

Isjoni. (2011). Cooperative Learning Efektifitas Pembelajaran Kelompok. Bandung: Alfabeta.

Kemdikbud. (2019). Hasil PISA Indonesia 2018: Akses Makin Meluas, Saatnya Tingkatkan Kualitas.

Tersedia di: https://www.kemdikbud.go.id/main/blog/2019/12/hasil-pisa-indonesia2018-akses-makin-meluas-saatnya-tingkatkan- 
kualitas\#: :text=Hasil\%20studi\%20PISA\%202018\%20yang,rata\%20skor\% $200 E C D \% 20$ yakni\%20487.

Mudjiono, D. (2006). Belajar dan Pembelajaran. Jakarta: Rineka Cipta.

Sudjana, N. (2013). Penilaian Hasil Proses Belajar Mengajar. Bandung: Remaja Rosdakarya.

Wahyono, B. (2017). Penerapan Model Pembelajaran Means Ends Analysis (MEA) pada Pembelajaran Matematika Materi Ajar Perbandingan. Didaktikum: Jurnal Penelitian Tindakan Kelas, 18(2), 1-6. 